\title{
PENINGKATAN KESEJAHTERAAN MASYARAKAT MELALUI OPTIMALISASI PEMANFAATAN POTENSI LOKAL DESA JEDONGCANGKRING KECAMATAN PRAMBON
}

\author{
Novita Diandaru ${ }^{1}$, Ary Setiono ${ }^{2}$ \\ ${ }^{1}$ Fakultas Keguruan dan Ilmu Pendidikan, Universitas PGRI AdiBuana Surabaya \\ ${ }^{2}$ Fakultas Ekonomi, Universitas PGRI AdiBuana Surabaya \\ Email :nopret07080ke@gmail.com ${ }^{1}$, arysetiono32@ gmail.com ${ }^{2}$
}

\begin{abstract}
Abstrak
Kuliah Kerja Nyata (KKN) adalah program yang ditempuh untuk mengakhiri studi Strata Satu (S1). KKN sebagai satu kegiatan pengabdian kepada masyarakat, dalam hal ini mahasiswa dapat mengamalkan ilmu, teknologi, dan seni yang didapat di Perguruan Tinggi guna memecahkan masalah yang ada di dalam masyarakat. Tujuan utama dari Kuliah Kerja Nyata adalah memacu pembangunan masyarakat dengan menumbuhkan motivasi kekuatan sendiri, mempersiapkan kader-kader pembangunan (stock holder) serta sebagai agen perubah (agen of change). Kelompok KKN UNIVERSITAS PGRI ADI BUANA SURABAYA tahun 2017 di desa Jedongcangkring mengambil beberapa kesimpulan: (a) saling membantu dan mendukung terlaksananya kegiatan KKN tanpa adanya kerja sama yang baik, (b) program kerja KKN tidak akan berjalan dengan lancar, (c) mencontoh cara berfikir mahasiswa untuk befikir modern, (d) Mahasiswa KKN memperoleh ilmu belajar cara hidup dari orang desa seperti gotrong royong ramah dan saling tolong menolong, (e) Teori yang didapat di bangku kuliah tidak semua sesuai dengan situasi dan kondisi lapangan, dan (f) Potensi desa Jedongcangkring telah dikelola cukup baik oleh masyarakat, sehimgga tercapai hasil yang memuaskan.
\end{abstract}

\section{PENDAHULUAN}

\section{a) Latar Belakang}

Kuliah Kerja Nyata (KKN) adalah pengaplikasian secara menyeluruh, dibidang disiplin ilmu pengetahuan dari teori-teori yang dimilikinya ke dalam sebuah wujud nyata pengabdian kepada masyarakat. Kuliah Kerja Nyata (KKN) merupakan program wajib yang harus ditempuh mahasiswa sebagai salah satu syarat untuk mengakhiri studi Strata Satu (S1), tentunya dengan persyaratan akademik yang sebelumnya sudah ditentukan dan dipenuhi oleh mahasiswa tingkat akhir.

Melalui program KKN tiap mahasiswa diharapkan dapat secara langsung membaur dengan masyarakat, menggali adanya berbagai potensi pada tiap daerah, dapat memecahkan segala permasalahan-permasalahan yang ada dimasyarakat, serta dapat menemukan segala pemecahan masalah dalam bentuk program kerja. KKN sebagai satu kegiatan pengabdian kepada masyarakat, dalam hal ini mahasiswa dapat mengamalkan ilmu, teknologi, dan seni yang didapat di Perguruan Tinggi guna memecahkan masalah yang ada di dalam masyarakat.

Tujuan utama dari Kuliah Kerja Nyata adalah memacu pembangunan masyarakat dengan menumbuhkan motivasi kekuatan sendiri, mempersiapkan kader-kader pembangunan (stock holder) serta sebagai agen perubah (agen of change). Tujuan utama lainnya adalah agar mahasiswa memperoleh pengalaman belajar yang berharga melalui keterlibatannya dalam masyarakat, dan secara langsung dapat menemukan, mengidentifikasi, merumuskan, serta memecahkan permasalahan dalam kehidupan bermasyarakat secara interdisipliner, komphrehensif, dan lintas sektoral. Berdasarkan hal diatas, Kuliah Kerja Nyata Mahasiswa UNIPA Surabaya 2017 sebagai bentuk aplikasi keilmuan yang dimiliki mahasiswa terhadap masyarakat dalam mengembangkan kompetensinya, diharapkan sudah selayaknya siap untuk menghadapi tantangan yang sedang berkembang pada era globalisasai seperti sekarang ini.

Kuliah Kerja Nyata mempunyai empat kelompok sasaran, yaitu mahasiswa, masyarakat, pemerintah daerah, dan perguruan tinggi. Bagi mahasiswa Kuliah Kerja Nyata mempunyai sasaran untuk membina mahasiswa agar menjadi motivator dan inovator. Sasaran bagi masyarakat dan Pemda adalah untuk memperoleh bantuan pemikiran, tenaga, serta IPTEK dalam merencanakan dan melaksanakan pembangunan. Sasaran bagi perguruan tinggi adalah untuk memperoleh umpan balik sebagai hasil pengintegrasian mahasiswa dalam masyarakat, sehingga kurikulum perguruan tinggi dapat disesuaikan dengan kondisi masyarakat yang diwakili oleh PEMDA yang terkait.

\section{b) Tujuan}

Secara umum Kuliah Kerja Nyata ( KKN ) mempunyai tujuan sebagai berikut ::

1. Mahasiswa memperoleh pengalaman belajar yang berharga melalui keterlibatan dalam masyakarat yang secara langsung menemukan, merumuskan, memecahkan dan 
menanggulangi permasalahan pembangunan secara pragmatis interdisipliiner.

2. Mahasiswa dapat memberikan pemikiran berdasarkan ilmu, tekhnologi dan seni dalam upya menumbuhkan, mempercepat gerak serta mempersiapkan kader pengembangan pembangunan.

3. Supaya perguruan tinggi dapat mencetak sarjana pengisi tekhnologi struktur dalam masyarakat yang lebih menghayati kondisi gerak dan permaslahan yang komplek dihadapi masyarakat dalam melaksanakan pengembangan pembangunan. Dengan demikian out put perguruan tinggi secara relatif menjadi siap pakai dan terlatih dalammenaggulangi permasalahan pembangunan yang lebih pragmatis dan interdisipliner.

4. Meningkatkan hubungan antara perguruan tinggi dengan pemerintah daerah, instasi terkait dan masyarakat sehingga perguruan tinggi lebih dapat berperan dan menyesuaikan pendidikan dan penelitiannya dengan tuntutan realistis dari masyarakat yang sedang pengembangan pembangunan.

\section{c) Manfaat}

Adapun manfaat yang ingin di capai dari laporan ini baik untuk civitas akademi maupun masyarakat adalah

\section{Bagi Mahasiswa KKN.}

1. Menambah pemahaman tentang cara berpikir dan bekerja secara praktis dalam menanggulangi berbagai permasalahan di masyarakat.

2. Menambah pemahaman dan penghayatan tentang kegunaan ilmu, kreativitas bagi pengembangan pembangunan.

3. Mahasiswa dapat memahami dan menghayati kesulitan yang di hadapi masyarakat dalam melaksanaka pengembangan pembangunan.

4. Mendewasakan cara berpikir dan daya nalar mahasiswa dalam melakukan telaah, perumusan dan pemecahan masalah.

5. Membina mahasiswa menjadi inovator, motivator, dinamisator.

6. Membentuk sikap, rasa cinta serta rasa tanggung jawab mahasiswa terhadap kemajuan masyarakat.

7. Menumbuhkan sifat profesionalisme dalam diri mahasiswa.

\section{Bagi Masyarakat dan Pemerintah}

1. Memperoleh bantuan tenaga dan pikiran dalam merencanakan dan melaksanakan pengembangan pembangunan.

2. Cara berpikir, bersikap dan bertindak dari masyarakat akan lebih sesuai dengan pembagunan.
3. Terbentuknya kader-kader penerus pengembangan dan pembangunan di masyarakat sehingga terjamin kelangsungan pengembangan dan pembangunan bangsa dan negara.

\section{Bagi Perguruan Tinggi.}

1. Memperoleh umpan balik sebagai hasil integrasi mahasiswa dengan masyarakat sehingga kurikulum dapat disesuaikan dengan kebutuhan di masyarakat.

2. Para dosen atau pengajar akan memperoleh berbagai pengalaman yang berharga dan menemukan berbagai masalah untuk pengembangan kegiatan penelitian.

3. Mempererat kerja sama antara lembaga UNIPA Surabaya dengan instansi lain dalam pelaksanaan pembangunan

\section{d) Batasan Masalah}

Batasan masalah yang digunakan dalam laporan KKNMahasiswa UNIPA Surabaya 2017 ini adalah warga atau masyarakat desa Jedongcangkring kecamatan Prambon Kabupaten Sidoarjo Jawa Timur.

\section{e) Kondisi lokasi}

Lokasi KKN yang berada di

DesaJedongcangkringyang

berkedudukandiKecamatan

PrambonKabupatenSidoarjo,adalahsebuah desa yang letaknya berjarak $18 \mathrm{Km}$ denganlama tempuh0,30jamdaripusatpemerintahankota

Sidoarjo.Desa

inimempunyailuasdaerahsekitar187.82ha, dengan ketinggiantanah12.00mdldiataspermukaanlaut,cura hhujan $339.00 \mathrm{~mm} /$ tahun, dansuhuudararata-

rata32.00C. Desa Jedongcangkringterdiridaritiga dusun,yaknidusun gempol,dusunjedong, dandusuncangkring. . Desa Jedongcangkring di batasi oleh beberapa desa diantaranya adalah:

Sebelah Utara : Desa Simo Ketawang Kecamatan Wonoayu.

Sebelah Selatan : Desa Kedung Kembar, Desa Jati Alun- alun Kecamatan Mojosari.

Sebelah Barat : Desa Cangkring Turi Kecamatan Tarik.

Sebelah Timur : Desa Kepunten Kecamatan Tulangan.

Pada Gambar 1 menggambarkan piramida penduduk Desa Jedongcangkring. Data yang kami peroleh tentang persebaran penduduk berdasarkan jenis kelamin hanya pada tahun 2016 sehingga kami menganalisis persebaran penduduk tanpa membandingkan dengan tahun- tahun yang sebelumnya. Dimana warna biru menggambarkan laki-laki, dan warna merah menggambarkan perempuan. Jika dilihat dari struktur piramida diatas 
maka dapat kita lihat bahwa penduduk Desa Jedongcangkring pada tahun 2016 termasuk pada tipe Granat atau Stasioner, yaitu piramida penduduk yang menggambarkan tingkat kelahiran yang hampir sama dengan tingkat kematian atau bersifat stasioner. Pertumbuhan penduduk cenderung tetap. Piramida ini menunjukkan jumlah penduduk muda, dewasa, dan tua hampir sama. Artinya desa jedongcangkring termasuk ke kategori desa maju terlihat tingkat dari angka kelahiran di desa Jedongcangkring ini tidak begitu tinggi, demikian pula dengan angka kematian relative rendah.

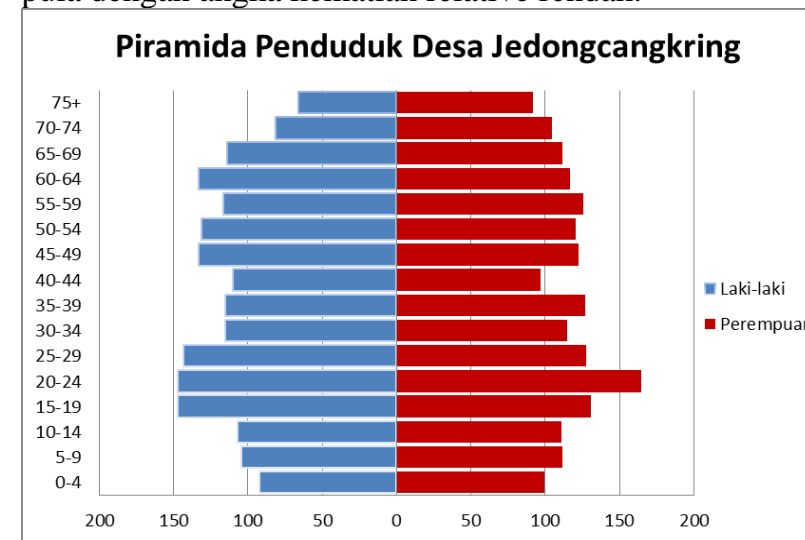

Gambar 1. Piramida Penduduk Desa Jedongcagkring Pada Tahun 2016

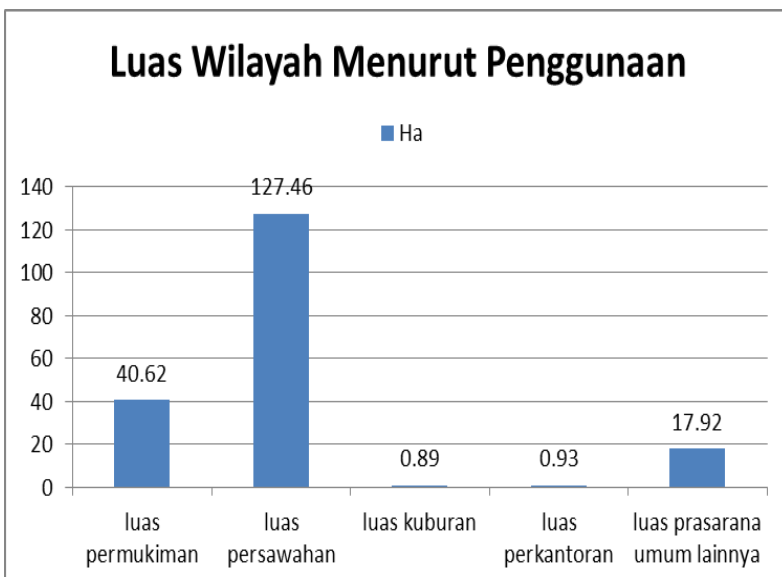

Gambar 2. Luar wilayah Desa Jedongcagkring menurut penggunaan

Gambar diatas menunjukkan bahwa luas wilayah menurut penggunaan paling tinggi digunakan untuk persawahan sebesar 127.46 ha, di ikuti permukiman sebesr 40.62 ha, dimana mayoritas penggunaan tanah yang ada di desa Jedongcangkring untuk persawahan atau bisa dikatan masyarakat desa jedongcangkring banyak yang cocok tanam.

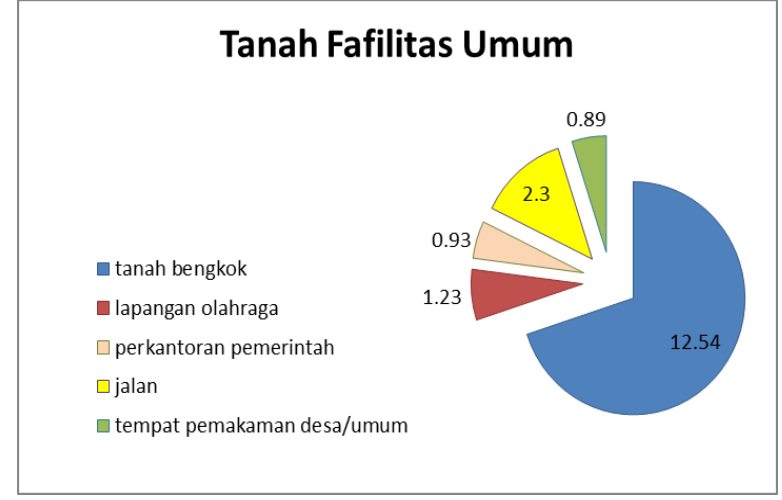

\section{Gambar 3. Luar wilayah Desa Jedongcagkring menurut penggunaan}

Gambar diatas menunjukkan bahwa luas tanah yang digunakan untuk fasilitas umum di desa Jedongcangkring dari 17.92 ha terbagi menjadi lima fungsi yaitu tanah bengkok, lapangan olahraga, jalan, perkantoran, pemakan desa, tetapi dari kelima penggunaan lahan fasilitas umum tersebut paling banyak digunakan untuk tanah bengkok dan yang paling sedikit di gunakan untuk pemakan desa.

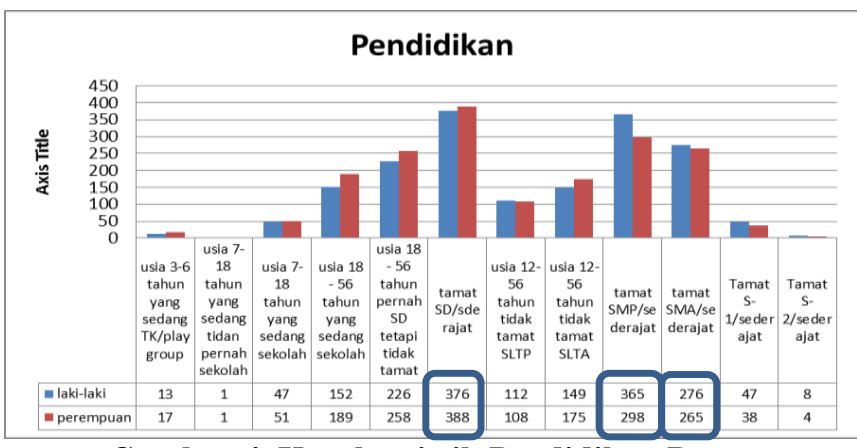

Gambar 4. Karakteristik Pendidikan Desa Jedongcagkring

Dari Gambar 4 di atas dapat diketahui bahwa masyarakat jedong cangkring paling tinggi berpendidikan SD/Sederajat, di ikuti tamat SMP/sederajat dan Tamat SMA/sederajat, atau dapat dikatakan bahwa kesadaran pendidikan 9 tahun sudah lumayan bagut bisa dilihat dari tamatan SMA/sederajat cukup tinggi yaitu sebesar 276 lakilaki dan 265 perempuan, tetapi untuk melanutkan ke perguruan tinggi masih kurang, karna dari 276 laki-laki dan 265 perempuan tersebut yang lulusan perguruan tinggi sangat minim yaitu 47 laki-laki dan 38 perempuan. 


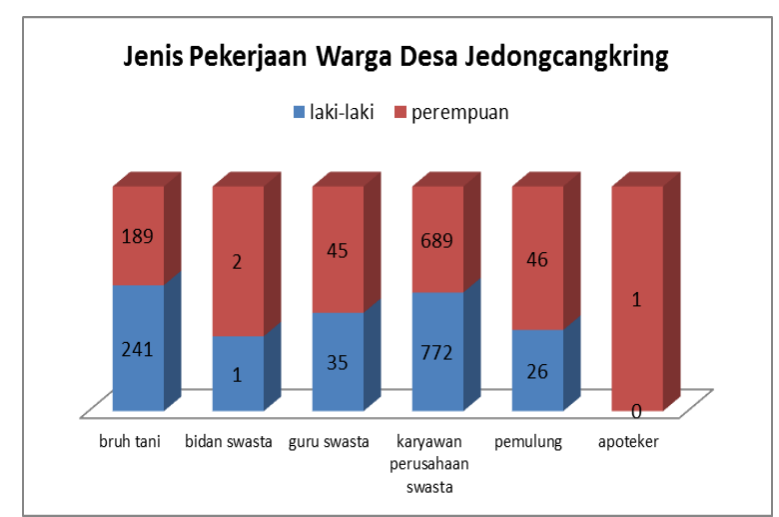

Gambar 5. Jenis Pekerjaan/Pencaharian Warga Desa Jedongcagkring

Dari Gambar 5 di bawah ini dapat menggambarkan bahwa masyarakat jedong cangkring mata pencahariaannya terdiri dari ada yang buruh tani, bidan swasta, guru swasta, karyawan swasta, pemulung, opoteker, namun dari enam mata pencaharian tersebut mayoritas masyarakat desa Jedongcangkring merupakan karyawan perusahaan swasta dan di ikuti buruh tani, tetapi tidak sampai separuh

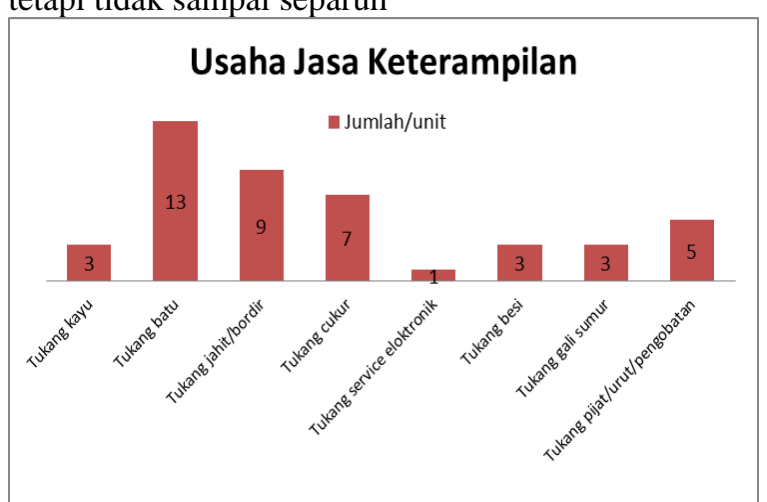

\section{Gambar 6. Jenis Jasa Keterampilan Desa Jedongcagkring}

Dari sekian banyak jenis usaha keterampilan desa jedongcangkring bisa dikatan sangat jarang, terlihat dari gambar di atas bahwa usaha jenis keteramplan yang ada hanya tukang kayu, taking batu, tukang jahit, tukang cukur, tukang service, tukang besi, tukang pijat, di mana masyarakat desa Jedongcangkring belum bisa dikatan masyarakat terampil, karna keterampilan yang ada sekarang ini masih belum tergolong ke dalam keterampilan yang modern itu terlihat pada gambar 6 di atas.

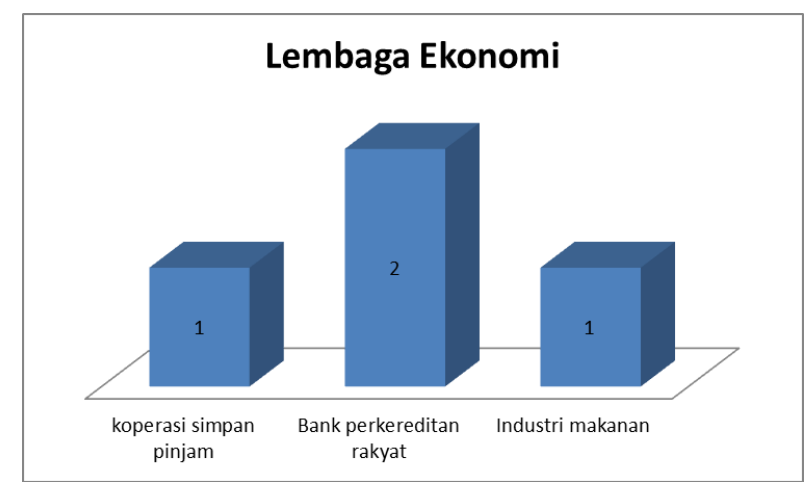

\section{Gambar 7. Karakteristik Pendidikan Desa Jedongcagkring}

Gambar 7. Menunjukan Lembaga ekonomi yang ada di desa Jedong cangkring yaitu koperasi siman pnjam, bank perkereditan rakyat, industry makanan terlihat dari gambar diatas, artinya masih sedikit sekali lembaga ekonomi yang ada di desa jedongcangkring.

\begin{tabular}{|r|l|}
\hline Jenis Usaha yang Ada Di Desa Jedongcangkring \\
a Series1 \\
Pengecer Gas dan bahan bakar minyak & 15 \\
Pengolahan kayu & 1 \\
Usaha peternakan & 1 \\
Usaha perikanan & 3 \\
Toko kelontong & 3 \\
Warung serba ada & 1 \\
Usaha Toko/kios & \\
Usaha Jasa Pengangkuran & 3 \\
\hline
\end{tabular}

\section{Gambar 8. Jenis usaha yang ada di Desa} Jedongcagkring

Dari sekian banyak jenis usaha yang seharunya bisa di kembangkan di desa, jenis usaha yang ada di desa Jedongkring meliputi pengesecer gas dan bahan bakar minya, pengolahan kayu, usaha peternakan, perikanan, took kelontong, warung serba ada, took/kios, uasaha jasa pengangkutan, artinya usaha masyarakat desa Jedongcangkring paling banyak usaha kios/took sebanya 75 orang, artinya dari usaha usaha yang belem ada bisa di kembangkan oleh pemerintah setempat, dan usaha yang sudah ada ini bisa dipertahankan dan di kembangkan lagi.

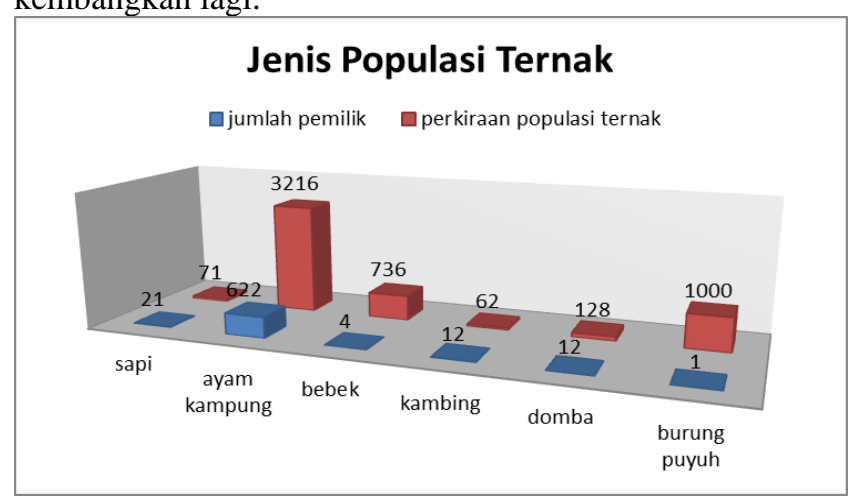




\section{Gambar 9. Populasi ternak Desa Jedongcagkring}

Dari gambar di atas dapat di ketahui bahwa jenis ternak yang ada di desa jedongcangkring terdiri dari sapi, ayam kampong, bebek, kambing, domba, burun puyuh, karna ternak yang ada termasuk ke katagori ternak yang mudah perawatannya, namun masyarakat desa Jedongcangkring paling banyak ternak ayam kampun, di ikuti sapi kambing dan domba sama, tetapi yang ternak burung puyuh hanya 1 orang dari sekeian banyaknya warga yang ada di disa. Jedongcangkring, artinya perawatan dari burung puyung ini lumayan sulit atau mahal, sehingga warga masih kurang minat.

\section{BAB II RENCANA PROGRAM KERJA}

Rencana program kerja yang akan dilakukan oleh Mahasiswa KKN UNIVERSITAS PGRI ADI BUANA SURABAYA2017 sebagai berikut.

\subsection{PENGELOLAHAN SAMPAH}

1. Melakukan penyuluhan mengenai sampah dan pengelolahan sampah kepada warga desa Jedongcangkring yang dilakukan di Balai Desa.

2. Melakukan praktik dalam pemanfaatan sampah kering dari bungkus kopi kepada warga desa Jedongcangkring yang dilakukan di Balai Desa.

3. Pembuatan Takakura.

4. Pembuatan lampion dari bahan bekas kardus, sendok dan botol aqua.

5. Pembuatan bros dan gantungan kunci dari bahan plastik bungkus kopi.

\subsection{PENGOLAHAN TOGA}

1. Memberi pengarahan kepada ibu PKK Desa JedongCangkring bahwa daun kelor dapat diolah menjadi nugget yang bergizi dan bernilai ekonomi.

2. Membuat nugget dari daun kelor yang memiliki banyak gizi di balai desa Jedongcangkring.

\subsection{SANITASI AIR}

1. Survey keadaan sanitasi lingkungan dan air bersih.

2. Penyuluhan sanitasi lingkungan dan air bersih.

\section{BAB III PELAKSANAAN PROGRAM KERJA}

Sebelum dilaksanakan kegiatan-kegiatan, diadakan sosialisasi terlebih dahulu dengan aparat pemerintah desa, ketua RW, tokoh masyarakat dan masyarakat desa Jedongcangkring. Hal ini bertujuan untuk menjelaskan maksud kedatangan mahasiswa KKN UNIPA Surabaya ke desa tersebut. Sosialisasi dimulai pada hari Rabu tanggal
30 Januari dengan mendatangi balai desa Jedongcangkring.

\subsection{Pengolahan Sampah}

Pelaksanaan program - program kerja dari Pengolahan Sampah sebagai berikut :

Survey pengolahan sampah disekitar desa jedongcangkring hari Selasa pada tanggal 4 februari 2017 di Desa Jedongcangkring Pukul 09.00 - 11.30 WIB, Penyuluhan dan pelatihan tentang pengolahan dan pemanfaatan sampahdi lakukan pada hari Selasa pada tanggal 7 Februari 2017 di balai Desa Jedongcangkring Pukul 09.00 - 11.30 WIB dengan mengundang ibu-ibu PKK. Pembuatan takakura dimulai tanggal 10 sampai 24 Februari 2017.

\subsection{Pengolahan Toga}

Pelaksanaan program - program kerja dari sebagai berikut

\begin{tabular}{|l|c|l|l|}
\hline No. & Hari/Tanggal & Waktu & Uraian Kegiatan \\
\hline 1. & $\begin{array}{c}\text { Senin, } \\
\text { 30Januari } \\
2017\end{array}$ & 09.00 & $\begin{array}{l}\text { Meminta ijin dan } \\
\text { menanyakan } \\
\text { jadwal pertemuan } \\
\text { ibu PKK }\end{array}$ \\
\hline 2. & $\begin{array}{c}\text { Selasa, 31 } \\
\text { Februari 2017 }\end{array}$ & 09.00 & Survey ke desa \\
\hline 3. & $\begin{array}{l}\text { Selasa, 12 } \\
\text { Februari 2017 }\end{array}$ & 09.00 & $\begin{array}{l}\text { Penyuluhan dan } \\
\text { praktek } \\
\text { pembuatan } \\
\text { olahan toga } \\
\text { nugget daun } \\
\text { kelor. }\end{array}$ \\
\hline
\end{tabular}

\subsection{Sanitasi Air}

Pelaksanaan program - program kerja dari sebagai berikut

Survey sanitasi di gunakan untuk mengetahui keadaan sanitasi air yang ada di desa Jedongcangkring hari Selasa pada tanggal 4 februari 2017 di Desa Jedongcangkring Pukul 09.00 - 11.30 WIB, Penyuluhan tentang sanitasi air di lakukan pada hari Selasa pada tanggal 4 februari 2017 di balai Desa Jedongcangkring Pukul 09.00 - 11.30 WIB dengan mengundang warga.

\section{BAB IV EVALUASI PROGRAM KERJA}

\subsection{Pengolahan Sampah STRENGTH(Kekuatan)}

- Membantu warga untuk menciptakan lingkungan yang bersih, nyaman dan tentram.

- Memberikan penghasilan kepada masyarakat dari hasil sampah yang tadinya tidak berguna.

WEEKNESS(Kelemahan)

- Sosialisasi yang belum dapat menjangkau masyarakat secara luas agar mau bergabung dengan bank sampah. 
- Masih kurangnya kesadaran diri yang dapat menarikantusiasme untuk mendorong membuat produk inovatif dari sampah.

- Keterbatasan pegawai dalam pengambilan sampah sehingga menimbulkan pencemaran dilingkungan rumah.

OPPORTUNITIES(Peluang)

- Meningkatkan penghasilan masyarakat melalui sampah yang selama ini diabaikan.

- Mengajarkan hidup bersih dan sehat serta menempatkan sampah sebagai sesuatu yang masih memiliki nilai guna pada masyarakat, khususnya pada anak-anak sejak dini.

- Mengembangkan kreatifitas dalam mengelola bank sampah dan menjadi desa yang teladan dalam penanganan sampah dengan cara inofatif, efektif dan efisien di tingkat Kabupaten Sidoarjo.

THREATS(Kendala)

- Masyarakat yang tidak sempat menjual sampahnya memilih untuk membuangsampah begitu saja atau hanya menimbun sampah sehingga menimbulkan penyakit seperti demam berdarah.

- Masyarakat dengan taraf perekonomian yang tinggi (kaya) akan mempengaruhi masyarakat untuk malas ikut serta dalam program.

- Masyarakat merasa malu dan jorok untuk mengelolah sampah.

\subsection{Pengolahan Toga}

Evaluasi yang digunakan menggunakan analisis SWOT setelah pelaksanaan program kerja di laksanakan dari Divisi Pengolahan Toga sebagai berikut :

STRENGTH (Kekuatan) : 1. Daun yang baik. Kandungan yang terdapat pada daun kelor diantaranya asam amino, $7 \mathrm{x}$ vitamin $\mathrm{C}$ dari jeruk, 4x vitamin A dari wortel, 3x potassium dari pisang, 4x kalsium dari susu. 2. Daun kelor memiliki berbagai manfaat diantaranya dapat mengobati alergi, sakit mata, herpes, kurap, rematik, pegallinu, cacingan dan dapat menghilangkan flek hitam pada wajah.

WEEKNESS (Kelemahan) : 1. Nugget daun kelor memiliki kelemahan diantaranya tidak bisa bertahan lama jika tidak di masukkan ke dalam lemari es karena tidak mengandung pengawet. Proses pembuatan nugget daun kelor membutuhkan waktu yang cukup lama, butuh ketelatenan untuk membuat nugget daun kelor.

OPPORTUNITIES(Peluang) : 1. Peluang pasar bisnis untuk pengolahan daun kelor saat ini sangat besar, hal ini dikarenakan kandungan gizi yang sangat banyak dan rasa daun kelor yang hambar cocok digunakan sebagai bahan campuran berbagai masakan. Pengolahan daun kelor menjadi nugget sangat efektif untuk peningkatan gizi anak yang tidak suka makan sayur.

THREATS(Kendala) : Kepercayaan masyarakat terhadap kekuatan mistis yang terdapat dalam daun kelor memunculkan mitosbahwa daun kelor bisa mengalahkan kekuatanmakhluk halus. Masyarakat percaya jika ada orang yang sakit dan tergeletak lama namun tidak juga meninggal, maka orang tersebut diduga memiliki kesaktian tertentu yang harus dilepas dari tubuhnya. Untuk melepas kesaktiannya, biasanya orang tersebut disapu dengan daun kelor hingga akhirnya meninggal. Karena kepercayaan itulah masyarakat merasa tabu untuk menggunakan daun kelor sebagai bahan masakan.

\subsection{Sanitasi Air}

Evaluasi yang digunakan menggunakan analisis SWOT setelah pelaksanaan program kerja di laksanakan dari Divisi Sanitasi Air sebagai berikut :

STRENGTH (Kekuatan) : Komitmen kepala desa dan juga warga untuk mewujudkan sanitasi air yang bersih dari sampah sangat tinggi.

WEEKNESS (Kelemahan) : Kurangnya penyediaan tempat sampah di sekitar halaman sehingga terjadi pembuangan sampah di bantaran kali

OPPORTUNITIES (Peluang) : Dukungan dana APBD untuk bantuan pengembangan sanitasi air dilingkungan desa Jedong Cangkring bakal terlaksana

THREATS(Kendala) : Tempat pengolahan dan pembuangan sampah akhir sedang dalam proses pembangunan, sehingga tempat pembuangan sampah belum tresedia

\section{Program tambahan}

Kerja Bakti di Kantor Desa merupakan program tambahan. Kerja bakti yang diadakan menjadikan kantor desa menjadi lebih bersih, rapi, dan indah. Selain itu kegiatan ini meringankan kerja para warga sekitar.

Posyandu setiap hari Rabu secara bergantian pada tiap-tiap dusun. Minggu pertama di dusun Cangkring, minggu kedua di dusun Jedong, dan minggu terakhir di dusun Gempol.

Bimbingan belajar diperuntukkan pada siswa SD setiap hari Senin sd Jum'at di Balai Desa Jedongcangkring. Bimbingan ini dimulai malam hari pukul 18.30 .

\section{BAB V PENUTUP Kesimpulan}

Berdasarkan hasil kegiatan, pengamatan, maupun pelaksanaan program kerja KKN yang 
telah direncanakan, disusun dan dilaksanakan. Maka kelompok KKN UNIVERSITAS PGRIADI BUANA SURABAYA tahun 2017 di desa Jedongcangkring mengambil beberapa kesimpulan

a. Keberhasilan KKN tidak lepas dari kerja sama antara mahasiswa dengan perangkat desa,masyarakat,serta semua pihak yang membantu dan mendukung terlaksananya kegiatan KKN tanpa adanya kerja sama yang baik, program kerja KKN tidak akan berjalan dengan lancar

b. Dengan adanya mahasiswa KKN para masyarakat mencoba mencontoh cara berfikir mahasiswa untuk befikir modern

c. Dengan adanya mahasiswa KKN masyarakat terbantu dengan bertambahnya informasi dan ilmu pengetahuan yang mereka peroleh dari mahasiswa KKN

d. Mahasiswa KKN memperoleh ilmu belajar cara hidup dari orang desa seperti gotrong royong ramah dan saling tolong menolong.

e. Teori yang didapat di bangku kuliah tidak semua sesuai dengan situasi dan kondisi lapangan

f. Potensi desa Jedongcangkring telah dikelola cukup baik oleh masyarakat, sehimgga tercapai hasil yang memuaskan, diantaranya :

- Kerjasama yang baik antara masyarakat, perangkat desa serta instansi terkait guna memperlancar pengembangan dan pembangunan desa.

- Perlu di tingkatakan Kepedulian masyarakat desa terhadap lingkungan.

- Perbaikan dan pemeliharaan penghijauan sehingga dapat membuka wilayah desa yang terisolisir dan dapat memperlancar transportasi.

- Keterbukaan aparat desa terhadap masyarakat, mampu menjalin hubungan komunikasi yang baik.

- Pemberdayaan swadaya masyarakat untuk menunjang pembangunanb dan pengmbangan Desa desa.

- Pemberdayaan BPD, LKMD, PKK, dan Karang Taruna.

Saran

Pelaksanaan kegiatan KKN dapat berjalan dengan baik jika di tunjang dengan kesungguhan dan motivasi yang tinggi dari mahasiswa dalam pengembangan masyarakat desa serta kerjasama dan koordinasi yang baik dengan seluruh lapisan masyarakat.

Agar pelaksanaan pembangunan di desa dapat berjalan dengan baik, maka di sarankan : a. Setiap kegiatan dan pengambilan keputusan hendaknya melibatkan semua unsur dan lapisan masyarakat dalam pembangunan desa.

b. Perlu adanya pembinaan, pelatihan keterampilan dan peningkatan pendidikan baik formal maupun nonformal.

c. Perlu adanya pembenahan dan pemerataan pembangunan di segala bidang.

\section{DAFTAR PUSTAKA}

http://simlitabmas.dikti.go.id/fileUpload/peng umuman/Panduan-Artikel-Hibah-PPM.pdf

http://docplayer.info/340881-Kumpulanartikel-kegiatan-pengabdian-kepadamasyarakat.htmlhttp://blogku8994.blogspot.c o.id/2014/08/proposal-pembuatan-rumahtoga.html

http://caramencegah.com/search/contoh+prop osal+tanaman+obat+keluarga https://www.scribd.com/doc/189149598/Prop osal-TOGA

https://id.wikipedia.org/wiki/Tanaman_obat_k eluarga

http://lemlit.undiksha.ac.id/media/1387.pdf

http://p2m.polibatam.ac.id/wpcontent/uploads/2011/12/Panduan-PenulisanArtikel-Program-Pengabdian-kepadaMasyarakat.pdf 
ABADIMAS ADI BUANA Volume 02, Nomer 2, 01 Oktober 2017 